\title{
Mitt liv med Ryssland
}

\author{
Magnus Ljunggren \\ Stockholm: Carlsson Bokförlag 2018 \\ 230 sider. ISBN 9789173318969
}

Omtalt av Jan Ivar Bjørnflaten [Professor i slaviske språk, Universitetet i Oslo, j.i.bjornflaten@ilos.uio.no]

Magnus Ljunggren (f. 1942) er pensjonert professor i russisk litteratur ved Göteborgs universitet. I boken Mitt liv med Ryssland ser han tilbake på mer enn 50 års beskjeftigelse med russisk litteratur og russiske forfattere. Ljunggrens livslange fascinasjon for Russland sprang ut av hans militære russiskstudier ved Tolkskolan i Uppsala. Studiene åpnet øynene for Sveriges historiske erkefiende og ikke minst for russisk litteratur, og ble avgjørende for Ljunggrens videre intellektuelle utvikling. Boken er i all hovedsak viet Ljunggrens møter og kontakt med russiske forfattere og forskere $\mathrm{i}$ et forhold som i utgangspunktet var asymmetrisk. De russiske forfatterne han møtte i Sverige på 60-, 70- og 80-tallet, var nøye utplukket og brifet av sovjetmyndighetene, mens de Ljunggren oppsøkte og møtte i Russland, i mange tilfeller var mer eller mindre marginaliserte i sovjetsamfunnet og hadde ofte lange opphold i de sovjetiske konsentrasjonsleirene bak seg. Her skrives det også om mindre kjente som Nina Gagen-Torn, med svenske aner, som hadde to opphold i Gulag-leirene i tilsammen 10 år. I det første fangenskapet satt hun i samme leir som Varlam Sjalamov i det beryktede konsentrasjonsleirområdet i Kolyma i nordøstligste Sibir. Begge ble viktige tidsvitner, og særlig kjent er Sjalamov blitt med sine skildringer av de sovjetiske leirkomplekser som mange mener overgår Solzjenicyns mer kjente beretninger.

Det ene bekjentskapet førte til det neste, og i løpet av flere tiår etablerte Ljunggren et omfattende nettverk i Russland. «For den som søker veier inn i Russland, la ham gå til dets genier og profeter», skriver filosofen Ivan Iljin (1883-1954) - en tenker Ljunggren har fattet interesse for, på godt og vondt, og som idag skal ha en høy stjerne i Kreml. Hovedbjelken i boken er således forfatterens beretninger om møter med en imponerende rekke interessante og særpregede personligheter: noen, som poeten Sergej Petrov, totalt uberørt av det samfunn som omgav dem, «i indre eksil»; andre i aktiv opposisjon, slik som de åtte som demonstrerte på Den røde plass 25. august 1968 mot okkupasjonen av Tsjekkoslovakia. 


\section{4 | JAN IVAR BJØRNFLATEN}

Sentral blant de mange forfattere Ljunggren omtaler, er Andrej Belyj (18801934). Denne forfatteren var da også gjenstand for hans første steg inn i forskningsverden og den som han hadde sitt første innlegg om på seminarene til professor Nils Åke Nilsson ved Stockholms universitet på 60-tallet. I 1983 disputerte så Ljunggren på en avhandling om Belyjs berømte roman Peterburg. Mange av Ljunggrens møter, i Russland og ellers i verden, dreier seg om mennesker som har hatt en eller annen tilknytning til Belyj. På bakgrunn av Ljunggrens livslange beskjeftigelse med Belyj og hans ry som ledende Belyj-ekspert, aner den uinnvidde leser Belyjs storhet og forventer stadig i løpet av lesningen av boken at denne skal behandles i mer detalj. Dette skjer imidlertid ikke i form av annet enn spredte hentydninger utover i teksten. Det samme gjelder mange av forfatterne som omtales. De omtales uten at leseren innvies videre i deres virke og betydning. Bokens svakhet blir således dens bredde som i flere tilfeller fremstår på bekostning av dybden.

Ljunggren ble kjent med Russland i Brezjnev-perioden som varte i 18 år fra 1964 til 1982, et tidsrom som ofte kalles stagnasjonsperioden, period zastoja, år som var preget av ideologisk forvitring og marxismens dødskamp i det anemiske sovjetsamfunnet, slik Ljunggren uttrykker det. Utad i det offentlige rom var dette et ensrettet, uniformert samfunn, mens det under overflaten rørte seg noe helt annet. En kunstner kunne på formiddagen i en TV-sending hylle Sovjetstaten som verdens mest demokratiske samfunn, mens samme kunstner om kvelden samme dag i et privat selskap advarte på det sterkeste mot sosialismen. Men Russland er paradoksenes land. Nettopp da Gorbatsjovs glasnost og perestrojka satte inn, ble Ljunggren erklært persona non grata i Sovjetunionen og nektet visum helt frem til 1990. Han ble innhentet av regimet akkurat da dets tid var i ferd med å renne ut.

Ljunggrens bok er en leseverdig beretning om russisk litteratur og hans dype interesse for og møter med det litterære og intellektuelle Russland. Men Russland kan være en utakknemlig partner som langt fra gjengjelder den velvillige interesse landet blir gjenstand for. Ljunggrens interesse for landet og litteraturen ble vakt mens stalinismens arv stadig knuget sovjetsamfunnet. Og etter 18 års stagnasjon under Brezjnev, etterfulgt av vel et tiårs tidvise kaotiske liberalisering, sitter på nytt en hersker på 18. året i Kreml. Ringen er sluttet - eller er den ikke det? 